\title{
Changing Epidemiology of Chronic Hepatitis C in Adana
} Adana Ilinde Kronik Hepatit C'nin Değișen Epidemiyolojisi

\author{
Ferit KUŞCU1, Süheyla KÖMÜR2, Ayşe Seza INAL2, Aslıhan Candevir ULU2, Behice KURTARAN2, \\ Yeşim TAŞOVA2, Berrin ÜNLÜ1, Dürdane MIDIKLI3, Zehra Doğan TOMUL1, Gürkan YILMAZ1, \\ Bedia Mutay SUNTUR1, Hasan Salih Zeki AKSU2 \\ ${ }^{1}$ Adana Numune Training and Research Hospital, Clinic of Infectious Diseases and Clinical Microbiology, Adana, Turkey \\ ${ }^{2}$ Çukurova University Faculty of Medicine, Department of Infectious Diseases and Clinical Microbiology, Adana, Turkey \\ ${ }^{3}$ Adana State Hospital, Infectious Diseases and Clinical Microbiology, Adana, Turkey
}

\section{ABSTRACT}

Objective: Our study aimed to demonstrate the epidemiological data of hepatitis $\mathrm{C}$ virus (HCV) and changes in its genotypic distribution which was observed in Adana in time.

Materials and Methods: The data from 369 patients who were on follow up with the diagnosis of chronic hepatitis C between January 1996 and March 2013, were reviewed retrospectively. The differences between the gender, age, and routes of transmission among the HCV patients with different genotypes were reviewed. Changes in the mean age, gender, and virus genotypes of the patients in our region by the years were evaluated.

Results: Genotype 1 was identified in 289 (78.3\%) patients, genotype 2 in 23 (6.2\%) patients, genotype 3 in $54(14.6 \%)$ patients and genotype 4 was identified in $3(0.8 \%)$ patients. When the genotypic distribution over the years was assessed, the rate of the patients with genotype 2 or 3 was $2.7 \%$ between 1996 and 2008, this rate was observed to increase to $44 \%$ between 2012 and 2013 . Sixty nine out of 77 (89.6\%) patients with genotype 2 or 3 were intravenous drug addicts.

Conclusion: In our region intravenous drug use-related HCV infection was increased in recent years. Decrease in the mean age of the patients, higher probability of occurrence among males and increased rates of genotype 2 and 3 were associated with this reason. (Viral Hepatitis Journal 2014; 20(1): 15-18)

Key words: Hepatitis $C$, genotype, epidemiology
ÖZET

Amaç: Bu çalışmada, Adana ilinde zaman içinde ortaya çıkan hepatit C virüsü (HCV) nün epidemiyolojik verileri ve genotip dağılımındaki değişikliklerin gösterilmesi amaçlanmıştır.

Gereç ve Yöntemler: Kronik hepatit C tanısıyla, Ocak 1996-Mart 2013 tarihleri arasında takip edilen 369 hastanın verileri retrospektif olarak değerlendirilmiştir. Çalışmada, farklı genotipe sahip hastalar arasındaki cinsiyet, yaş ve bulaş yolu farklııkları ve yıllara göre bölgemizdeki hastaların yaş ortalaması, cinsiyetleri ve virüs genotiplerindeki değişimler ele alınmıştır.

Bulgular: Genotip 1, $289(\% 78,3)$ hastada; genotip 2, $23(\% 6,2)$ hastada; genotip $3,54(\% 14,6)$ hastada; genotip 4 ise $3(\% 0,8)$ hastada tespit edildi. YIllara göre genotip dağılımı incelendiğinde; $1996-2008$ yılları arasında genotip 2 ve 3'e sahip hastaların oranı \%2,7 iken, 2012-2013 yılları arasnda bu oranın \%44'e yükseldiği görüldü. Genotip 2 veya 3'e sahip 77 hastanın $69(\% 89,6)$ 'sinda intravenöz ilaç bağımlıı̆̆ı vardı.

Sonuç: Son yıllarda damar içi ilaç kullanımına bağı HCV enfeksiyonu bölgemizde artış göstermiştir. Hastaların yaş ortalamasındaki düşüş, erkek cinsiyette daha sık görülür olması ve genotip 2 ve 3 oranlarındaki artış bu nedene bağlanmış̧ır. (Viral Hepatit Dergisi 2014; 20(1): 15-18)

Anahtar Kelimeler: Hepatit C, genotip, epidemiyoloji

\section{Introduction}

Chronic hepatitis $\mathrm{C}$ virus $(\mathrm{HCV})$ is the leading cause of chronic hepatitis and related complications around the world and is an important public health problem. Epidemiological studies have revealed an increase in the prevalence of $\mathrm{HCV}$ infection all around the world (1). The prevalence of $\mathrm{HCV}$ is reported as $1-1.9 \%$ in our country (2).
$\mathrm{HCV}$ is a single stranded RNA virus in the Flaviviridae family and since the genomic changes may develop with ease, various genetic sequences may occur. According to the analysis of nucleic acid sequences, at least 6 major genotypes and more than 100 subtypes of HCV were detected (3). The dominant $\mathrm{HCV}$ genotype was detected as $1 \mathrm{~b}$ in the studies conducted in our country $(4,5,6)$. However during the recent years, changes were reported in the age and in the HCV genotype distributions. 
Intravenous drug abuse may be considered as responsible for the increase of HCV infection, particularly in young individuals. Furthermore the dominance of HCV genotype 3 among these individuals attracts attention $(1,6,7)$.

Our study aimed at demonstrating the epidemiological changes in $\mathrm{HCV}$ epidemiology and in genotypic distribution among the causes of HCV infection over time.

\section{Material and Methods}

The data from 369 patients who were admitted to the infectious diseases clinics of three large hospitals (Cukurova University Balcalı Hospital, Adana Numune Training and Research Hospital, Adana State Hospital) in Adana and who were on follow up with the diagnosis of chronic HCV between January 1996 and March 2013, were reviewed retrospectively. The demographic data of the patients such as age and gender, HCV genotypes and potential routes of transmission were investigated and recorded. Genotype detections were conducted with different methods in the various hospitals. The differences between the routes of transmission, age, gender among the patients with different genotypes were reviewed. Changing in virus genotypes, gender and the mean age of the patients by the years in our region were evaluated. Statistical analysis was performed using the SPSS software version 15. The variables were investigated using Kolmogorov-Smirnov test to determine whether or not they are normally distributed. Descriptive analyses were presented using means and standart deviations. Student's t-test was used to compare mean ages and HCV-RNA values between the genotype 1,4 and genotype 2,3 groups. Odds ratios (OR) were calculated for gender and iv drug abuse between the groups. A p-value of less than 0.05 was considered to show a statistically significant result.

\section{Results}

Two hundred twenty-two out of 369 patients who were included in the study were $(60 \%)$ male and 147 patients were (40\%) female. The mean age was $47 \pm 16$ years. The genotypic distribution among the patients was as follows: Genotype 1 was identified in 289 (78.3\%) patients, genotype 2 was in $23(6.2 \%)$ patients, genotype 3 in 54 (14.6\%) patients and genotype 4 was identified in $3(0.8 \%)$ patients.

When the genotypic distributions were divided into groups, $292(79 \%)$ patients were genotypes $(1,4)$ and $77(21 \%)$ were genotypes $(2,3)$. The mean age of group of genotype 2 and 3 patients was significantly lower than that of the group of genotype1 and 4 patients $(p<0.0001)$. When assessed in terms of gender distribution, the numbers of males and females were close in the genotypes 1 and 4 patients. A statistically significant male dominance was observed in the group of genotype $(2,3)$. patients (OR:7.8; 95\% Cl: 3.6-16.8; $\mathrm{p}<0.001)$. When the two groups were compared, 69 out of 77 (89.6\%) patients were intravenous drug addicts and the probability of drug addiction in this group was statistically significantly higher than that of the group of genotypes $(1,4)$. patients (OR: 237.2 ; $95 \% \mathrm{Cl}$ : 83.1 677.1; $\mathrm{p}<0.0001)$. No difference was detected between the groups in terms of HCV RNA values (Table 1).

When the genotypic distribution over the years was assessed, while the rate of the genotype 2 and 3 patients was $2.7 \%$ between 1996 and 2008, this rate was observed to increase by $44 \%$ in $2012-2013$ (Figure 1). Similarly, while the ratio of male patients was $47.8 \%$ between 1996-2008, this rate was increased by $69.2 \%$ between $2012-2013$. Furthermore the mean age of the patients decreased over the years and while the mean age was $49 \pm 12$ years between 1996-2008, it was detected as $42 \pm 17$ years during the period of 2012-2013 (Table 2, Figure 2).

\section{Discussion}

HCV genotypes reveal different distributions in different geographic regions. Genotypes 1, 2 and 3 are the most common types and were observed in Europe, North America, China, Japan

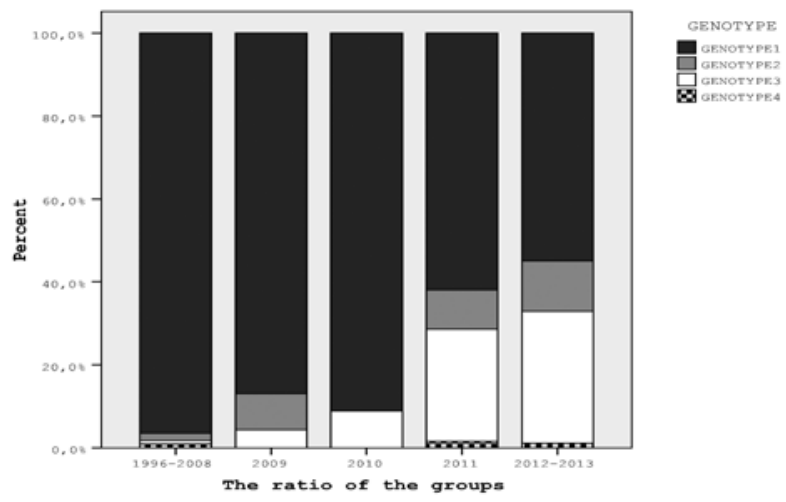

Figure 1. HCV genotypic distribution by the years.

Table 1. Demographic and laboratory data of the patients by HCV genotypes

\begin{tabular}{|l|l|l|l|}
\hline & GENOTYPES 1-4 & GENOTYPES 2-3 & P value (OR) \\
\hline Patients' number & 292 & 77 & - \\
\hline Mean age \pm SD & $52 \pm 13$ & $29 \pm 12$ & $\mathrm{p}<0.0001$ \\
\hline $\begin{array}{l}\text { Gender } \\
\text { Male }\end{array}$ & $153(52.4 \%)$ & $69(89.6 \%)$ & \\
$\quad$ Female & $139(47.6 \%)$ & $8(10.4 \%)$ & OR: $7.8(3.6-16.8)$ \\
\hline $\begin{array}{l}\text { IV Drug Abuse } \\
\text { Yes }\end{array}$ & $5(1.7 \%)$ & $62(80.5 \%)$ & $\mathrm{p}<0.0001$ \\
$\quad$ No & $287(98.3 \%)$ & $15(19.5 \%)$ & OR: $237.2(83.1-677.1)$ \\
\hline HCV RNA (IU/ml) \pm SD & $2010388 \pm 3171142$ & $1508701 \pm 3336689$ & $\mathrm{p}<0.0001$ \\
\hline
\end{tabular}




\begin{tabular}{|l|l|l|l|l|l|}
\hline Table 2. The changes by the years in the mean ages, male gender and the rates of HCV genotype 2-3 among overall patients \\
\hline & $\mathbf{1 9 9 6 - 2 0 0 8}$ & $\mathbf{2 0 0 9}$ & $\mathbf{2 0 1 0}$ & $\mathbf{2 0 1 1}$ & $\mathbf{2 0 1 2 - 2 0 1 3}$ \\
\hline Mean age \pm SD & $49 \pm 12$ & $50 \pm 15$ & $56 \pm 14$ & $44 \pm 19$ & $42 \pm 17$ \\
\hline The rate of male patients (\%) & $47.8 \%$ & $50 \%$ & $66.1 \%$ & $71.4 \%$ & $69.2 \%$ \\
\hline Genotype 2-3 (\%) & $2.7 \%$ & $13 \%$ & $8.9 \%$ & $36.5 \%$ & $44 \%$ \\
\hline
\end{tabular}

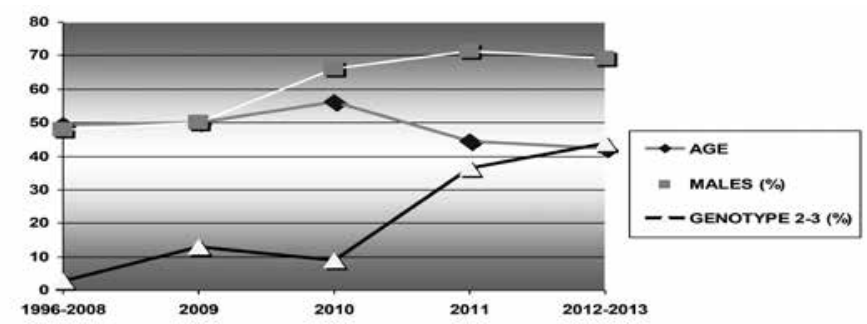

Figure 2. The changes in the mean age; the rates of male patients in the overall number of patients; and at the rate of genotype 2-3.

and Australia. Genotype 3 is particularly found in Scots blood donors, Southeastern Asia countries and young patients (2). Changes were reported on the distribution of HCV genotypes over years in certain regions of Europe and Africa. This change is assumed to be related to the differentiation of the migration and route of transmission of HCV (8).

The HCV genotype 1 viruses those are commonly encountered in Turkey were suggested to enter Turkey between 1920 and 1930 and it was asserted that the use of non sterile injectors might contribute to the spread of this virus. Therefore, it is suggested that the use of disposable injectors and scanning of the blood and blood products for HCV may initiate a decrease in the genotype 1 infection (4). In our study, genotype 1 was also found at the highest rate similarly to the medical literature (78.9\%). Genotype $1 \mathrm{~b}$ was found as the most common genotype in various studies conducted in our country $(90-100 \%) .(4,5,6,9)$.

In a study of 72 cases of HCV conducted by Yarkın et al. in our region in 2000, genotype 1 was found at a rate of $96.7 \%$ and genotype 2 was detected at a rate of $3.3 \%$ (10). In a study of 236 patients conducted in Mersin by Tezcan et al. in 2012, the rate of genotype 1 was reported as $92.3 \%$, genotype 3 was $4.2 \%$, genotype 2 was $2.1 \%$, genotype 4 was $0.8 \%$ and genotype 6 was reported as $0.4 \%(11)$. In our study the rate of genotypes 2 and 3 was found as 2,7\% between 1996 and 2008. However the rate was rapidly increased from 2009 and reached by $44 \%$ in 2012 and the first months of 2013. This rate has never been reported before from any region in our country.

It is not always possible to determinate the route of transmission of HCV infection (9). Intravenous drug abuse has been implicated as the main route of transmission of HCV infection in developed countries (1). In a large study on the prevalence of HCV infection in the United States of America (USA) a history of intravenous drug abuse was detected in $48.4 \%$ of the anti-HCV positive cases (12). The most common risk factor was defined as intravenous drug abuse in the European countries such as Norway, Italy and Great Britain (9). Intravenous drug abuse related HCV transmission has been very rarely reported in our country $(2,13)$.

In a study conducted by Karaca et al., investigating the routes of transmission of HCV infection in 320 patients with $\mathrm{HCV}$ infection, the rate of intravenous drug abuse was detected as $3.1 \%$ (13). However, a history of syringe sharing and intravenous drug abuse was present in a rate of $80.5 \%$ among the patients infected by the genotypes 2 and 3 viruses. The rate intravenous drug abuse was only $1.7 \%$ among the genotype one patients.

$\mathrm{HCV}$ infection shows the differences by geographical regions as well as by certain age groups. Although USA, Australia, Spain, Japan and Turkey show big differences in terms of HCV infection, they have a similar HCV incidence (1.0\%-1.9\%). (2,14). However age specific prevalences were significantly different among these countries. The prevalence is highest between 30 and 49 years of age in the USA and between 20 and 29 years of age in Canada. Similarly, the prevalences were highest in the age range of 20 to 40 in Australia and North European countries $(9,14)$. In the studies conducted in Turkey, the prevalence was reported higher over the age of 50 compared to the younger population $(13,15)$. Similarly to the data from our country, while the prevalence was higher over the age of 50 in our study in the past years, in the recent years, a significant decrease was discerned in the age range of the disease (Figure 2).

In the HCV epidemiology; we believe that the main determinant factor is the route of transmission in terms of the differences between the age groups, genotypes and gender. Namely, in the countries such as USA where the intravenous drug abuse ranked first among the routes of transmission of $\mathrm{HCV}$, the highest prevalence was found between 20 and 40 years of age. In a similar way, in the geographical regions where intravenous drug abuse is the essential route of the transmission of the disease, it is observed that the male/female ratio increases due to the higher rates of intravenous drug addiction among males $(2,9,15)$. In the countries such as Turkey where intravenous drug abuse does not rank first among the routes of transmission, the disease develops in the older ages and no difference was detected between the prevalences among the males and females (13). All of the our patients were citizens of Turkey and any immigration activities were not reported in recent years in Adana.

In conclusion, our study results showed that the increased rate of genotype 2 and 3 in patients with HCV infection may be related to the increased prevalence of $\mathrm{HCV}$ among the intravenous drug user. Besides, the significant decrease in the mean age of the patients and higher prevalence of $\mathrm{HCV}$ among the males may be related to this change in the route of transmission of the virus.

\section{Conflict of interest: None declared.}

\section{References}

1. Shepard CW, Finelli L, Alter MJ. Global epidemiology of hepatitis C virus infection. Lancet Infect Dis. 2005; 5: 558-567. 
2. Barut HŞ, Günal Ö. Global and national epidemiology of hepatitis C. Klimik Journal. 2009; 22: 38-43.

3. Argentini C, Genovese D, Dettori S, Rapicetta M. HCV genetic variability: from quasispecies evolution to genotype classification. Future Microbiol. 2009; 4: 359-373.

4. Abacioglu YH, Davidson F, Tuncer S, Yap PL, Ustacelebi S, Yulug $\mathrm{N}$, Simmonds $\mathrm{P}$. The distribution of hepatitis $\mathrm{C}$ virus genotype in Turkish patients. J Viral Hepat 1995; 2: 297-301.

5. Çiftçi IH, Er H, Aşık G, Aktepe OC, Altındiş M. The distribution of genotype of the hepatitis c virus (HCV) RNA positive patients. 2009:10: 21-24.

6. Keskin F, Çiftçi S, Türkoğlu S, Badur S. Transmission routes of chronic hepatitis $\mathrm{C}$ and their relation to HCV genotypes. Turk $\mathrm{J}$ Gastroenterol. 2010; 21: 396-400.

7. Ozbek E, Ozekinci T, Mese S, Atmaca S. Hepatitis C virus genotypes are changing in the southeast of Turkey. Biotechnol Biofuels. 2009; 23: 1521-1523.

8. Esteban JI, Sauleda S, Quer J. The changing epidemiology of hepatitis C virus infection in Europe. J Hepatol. 2008; 48: 148162.

9. Cornberg M1, Razavi HA, Alberti A, Bernasconi E, Buti M, Cooper C, Dalgard O, Dillion JF, Flisiak R, Forns X, Frankova S, Goldis A, Goulis I, Halota W, Hunyady B, Lagging M, Largen A, Makara M, Manolakopoulos S, Marcellin P, Marinho RT, Pol
S, Poynard T, Puoti M, Sagalova O, Sibbel S, Simon K, Wallace C, Young K, Yurdaydin C, Zuckerman E, Negro F, Zeuzem S. A systematic review of hepatitis $C$ virus epidemiology in Europe, Canada and Israel. Liver Int. 2011; 31(Suppl 2): 30-60.

10. Yarkın F, Hafta A. The distribution of hepatitis C virus (HCV) genotypes in patients with chronic hepatitis $\mathrm{c}$ infection. Viral Hepatitis Journal. 2000; 6: 164-168.

11. Tezcan S1, Ulger M, Aslan G, Yaraş S, Altıntaş E, Sezgin O, Emekdaş G, Gürer Giray B, Sungur MA. Determination of hepatitis C virus genotype distribution in Mersin province, Turkey. Mikrobiyol Bul. 2013; 47: 332-338.

12. Armstrong GL, Wasley A, Simard EP, McQuillan GM, Kuhnert $\mathrm{WL}$, Alter MJ. The prevalence of hepatitis $\mathrm{C}$ virus infection in the United States, 1999 through 2002. Ann Intern Med. 2006; 144: 705-714.

13. Karaca C, Cakaloğlu Y, Demir K, Ozdil S, Kaymakoğlu S, Badur S, Okten A. Risk factors for the transmission of hepatitis $C$ virus infection in the Turkish population. Dig Dis Sci. 2006; 51: 365369.

14. Alter MJ. Epidemiology of hepatitis C virus infection. World J Gastroenterol. 2007; 13: 2436-2441.

15. Altuglu I, Soyler I, Ozacar T, Erensoy S. Distribution of hepatitis $C$ virus genotypes in patients with chronic hepatitis $C$ infection in Western Turkey. Int J Infect Dis. 2008; 12: 239-244. 